\title{
Optimalisasi Kader Dalam Pencegahan COVID 19 Di Desa Pasir Lor Kecamatan Karanglewas Banyumas
}

\section{Optimization Of Cadres In The Prevention Of COVID 19 In Pasir Lor Village, Karanglewas District, Banyumas}

\author{
Sumarni $^{1}$, Eni Indriyani ${ }^{2}$ \\ 1,2 Program Studi Kebidanan, STIKes Muhammadiyah Gombong \\ Corresponding Author: email : sumarni2880@gmail.com
}

Kata Kunci: optimalisasi kader; pencegahan; covid-19

Keywords:

Covid-19

prevention; Optimization of cadres

\section{ABSTRAK}

Corona virus Disease 2019 (COVID-19) adalah penyakit jenis baru yang belum pernah diidentifikasi sebelumnya pada manusia. COVID 19 dapat menular dari manusia ke manusia melalui percikan batuk/bersin (droplet). Untuk mencegah penyebaran infeksi melalui cuci tangan secara teratur menggunakan sabun dan air bersih, menerapkan etika batuk dan bersin, menghindari kontak secara langsung dengan ternak dan hewan liar serta menghindari kontak dekat dengan siapapun yang menunjukkan gejala penyakit pernapasan seperti batuk dan bersin. Tujuan kegiatan ini adalah untuk meningkatkan pengetahuan dan ketrampilan kader tentang pencegahan Covid 19 melalui pelatihan pencegahan Covid 19. Metode yang akan digunakan untuk merealisasi program ini yaitu melalui persiapan, pelaksanaan, evaluasi dan rencana tindak lanjut. Hasil menunjukan kader yang mempunyai pengetahuan baik meningkat dari $16 \%$ menjadi $40 \%$, sedangkan ibu kader yang mempunyai pengetahuan cukup meningkat dari sebelumnya $24 \%$ menjadi $32 \%$. Ibu kader yang mempunyai pengetahuan kurang mengalami penurunan dari $60 \%$ menjadi $28 \%$. Kesimpulan; kegiatan optimalisasi kader kesehatan dalam upaya pencegahan Covid 19 di Desa Pasir Lor berlangsung dengan efektif dan efisiens.

ABSTRACT
Corona virus Disease 2019 (COVID-19) is a new type of disease that has never been
identified before in humans. COVID 19 can be transmitted from human to human
through coughing / sneezing (droplet). To prevent the spread of infection is through
regular hand washing with soap and clean water, applying the ethics of coughing and
sneezing, avoiding direct contact with livestock and wild animals and avoiding close
contact with anyone who shows symptoms of respiratory illnesses such as coughing
and sneezing. The objective of this activity is to increase the knowledge and skills
of cadres about prevention of Covid 19 through Covid 19 prevention training. The
method to be used to realize this program is through preparation, implementation,
evaluation and follow-up plans. The results showed cadres who had good knowledge
increased from $16 \%$ to $40 \%$, while cadres mothers who had sufficient knowledge
increased from the previous $24 \%$ to $32 \%$. Cadres who have less knowledge have
decreased from $60 \%$ to $28 \%$. Conclusion; the optimization of health cadres in the
prevention of Covid 19 in Pasir Lor Village took place effectively and efficiently




\section{PENDAHULUAN}

Corona virus Disease 2019 (COVID-19) adalah penyakit jenis baru yang belum pernah diidentifikasi sebelumnya pada manusia. Penyebab COVID-19 disebut Sars-CoV-2. Virus corona merupakan golongan zoonosis (ditularkan antara hewan dan manusia). Coronavirus Disease 2019 (COVID-19) masih satu keluarga dengan SARS dan MERS.

Penelitian menyebutkan bahwa SARS ditransmisikan dari kucing luwak (civet cats) ke manusia dan MERS dari unta ke manusia. Adapun, hewan yang menjadi sumber penularan COVID-19 ini masih belum diketahui.Tanda dan gejala umum infeksi COVID-19 antara lain gejala gangguan pernapasan akut seperti demam, batuk dan sesak napas. Masa inkubasi rata-rata 5-6 hari dengan masa inkubasi terpanjang 14 hari.

Pada kasus COVID 19 yang berat dapat menyebabkan pneumonia, sindrom pernapasan akut, gagal ginjal, dan bahkan kematian. Tanda-tanda dan gejala klinis yang dilaporkan pada sebagian besar kasus adalah demam, dengan beberapa kasus mengalami kesulitan bernapas, dan hasil rontgen menunjukkan infiltrat pneumonia luas di kedua paru.

Pada 31 Desember 2019, WHO China Country Office melaporkan kasus pneumonia yang tidak diketahui etiologinya di Kota Wuhan, Provinsi Hubei, Cina. Pada tanggal 7 Januari 2020, Cina mengidentifikasi pneumonia yang tidak diketahui etiologinya tersebut sebagai jenis baru coronavirus (corona virus disease, COVID 19).
Pada tanggal 30 Januari 2020 WHO telah menetapkan sebagai Kedaruratan Kesehatan Masyarakat Yang Meresahkan Dunia/Public Health Emergency of International Concern (KKMMD/PHEIC). Penambahan jumlah kasus COVID-19 berlangsung cukup cepat dan sudah terjadi penyebaran antar negara.

Berdasarkan bukti ilmiah, COVID 19 dapat menular dari manusia ke manusia melalui percikan batuk/bersin (droplet), tidak melalui udara. Orang yang paling berisiko tertular penyakit ini adalah orang yang kontak erat dengan pasien COVID 19 termasuk yang merawat pasien COVID 19.

Rekomendasi standar untuk mencegah penyebaran infeksi adalah melalui cuci tangan secara teratur menggunakan sabun dan air bersih, menerapkan etika batuk dan bersin, menghindari kontak secara langsung dengan ternak dan hewan liar serta menghindari kontak dekat dengan siapapun yang menunjukkan gejala penyakit pernapasan seperti batuk dan bersin.

Coronavirus bersifat sensitif terhadap panas dan secara efektif dapat diinaktifkan oleh desinfektan mengandung klorin, pelarut lipid dengan suhu $56^{\circ} \mathrm{C}$ selama 30 menit, eter, alkohol, asam perioksiasetat, detergen non-ionik, formalin, oxidizing agent dan kloroform. Klorheksidin tidak efektif dalam menonaktifkan virus.

Selain itu, menerapkan Pencegahan dan Pengendalian Infeksi (PPI) saat berada di fasilitas kesehatan terutama unit gawat darurat. Berdasarkan cara penularan tersebut maka masyarakat perlu memahami dan mampu melakukan upaya pencegahan Covid 19. 
Untuk meningkatkan pengetahuan dan kesadaran masyarakat maka peran serta kader kesehatan sangat diperlukan dalam upaya menyebarluaskan informasi tentang Covid 19 tersebut.

Tujuan kegiatan ini adalah untuk meningkatkan Pengetahuan dan ketrampilan kader tentang pencegahan Covid 19.

\section{METODE}

Metode yang akan digunakan untuk merealisasi program ini yaitu:

1. Tahap 1: Persiapan

Pada tahap pertama melakukan persiapan proses kegiatan meliputi koordinasi dengan Bidan desa dan koordinator kader dan tim untuk penentuan jadwal bersama. pembuatan media booklet dan kuesioner

2. Tahap 2: Pelaksanaan Kegiatan Pada tahap kedua dilakukan kegiatan pengabdian meliputi beberapa kegiatan yaitu:

a. Peningkatan pengetahuan bu Kader Tentang Covid 19

b. Pelatihan pencegahan Covid 19 melalui GERMAS (Gerakan Masyarakat Hidup Sehat)

3. Tahap 3: Evaluasi

Evaluasi kegiatan akan dilakukan melalui pemberian kuesioner kepada Ibu kader untuk mengukur tingkat pengetahuan sebelum dan sesudah kegiatan.

\section{Rencana Tindak Lanjut}

Melakukan monitoring kemampuan ibu kader tentang upaya pencegahan covid 19.

\section{HASIL DAN PEMBAHASAN}

\section{A. Persiapan}

Persiapan kegiatan dilaksanakan dengan melakukan koordinasi dengan Bidan desa dan koordinator Kader Kesehatan di wilayah Desa Pasir Lor Kecamatan Karanglewas Banyumas. Pada kegiatan persiapan Tim pengabdian melakukan pertemuan dengan pembahasan mengenai teknik kegiatan dan pembagian tugas masingmasing. Tim pengabdian juga melakukan kegiatan persiapan materi berupa kuesioner, bookletpendukung kegiatan.

\section{B. Pelaksanaan}

Kegiatan ini diikuti 25 kader. Kegiatan pengabdian telah dilakukan melalui 3 kegiatan yang meliputi kegiatan pendidikan kesehatan tentang Covid 19, pelatihan pencegahan Covid 19 dengan GERMAS, dan simulasi pencegahan Covid 19 melalui cuci tangan 6 langkah, pemakaian masker, etika batuk dan bersin.

Selain itu juga diberikan anjuran untuk masyarakat melalui kader untuk menyediakan sarana cuci tangan disetiap rumah, pemakaian masker setiap keluar rumah. 


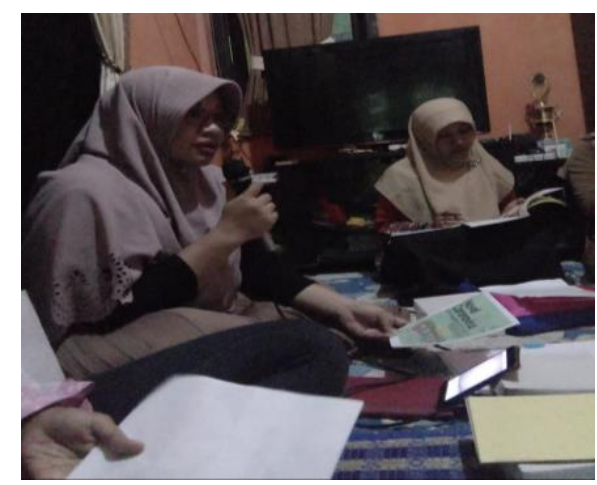

Gambar 1. Pelaksanaan Kegiatan

\section{Evaluasi}

Evaluasi kegiatan pengabdian dilakukan sebagai upaya untuk mengukur ketercapaian program kegiatan yang telah dilaksanakan. Evaluasi kegiatan dalam program pengabdian ini meliputi:

1. Tingkat Pengetahuan ibu Kader tentang Covid 19

2. Tingkat ketrampilan Ibu Kader tentang pencegahan Covid 19 dengan GERMAS.

Evaluasi terhadap tingkat pengetahuan ibu kader mengenai
Covid 19 dilakukan melalui kegiatan pre test dan post test. Hal ini dilakukan karena sebagai upaya bagi tim kegiatan untuk memastikan terjadi peningkatan pengetahuan setelah program dilakukan.

Tingkat pengetahuan ibu Kader ini penting karena dengan memiliki tingkat pengetahuan yang baik tentang Covid 19 ini diharapkan ibu kader dapat memberikan sosialisasi pada masyarakat

Tabel 1 Tingkat Pengetahuan ibu Kader tentang Covid 19 pre test

\begin{tabular}{lrr}
\hline \multicolumn{1}{c}{ Katgori } & Jumlah & \multicolumn{2}{c}{ Prosentase } \\
\hline Kurang & 15 & $60 \%$ \\
Cukup & 6 & $24 \%$ \\
Baik & 4 & $16 \%$ \\
Total & 25 & $100 \%$ \\
\hline
\end{tabular}

Tabel 2. Tingkat Pengetahuan ibu Kader tentang Covid 19 post test

\begin{tabular}{|c|c|c|}
\hline Katagori & Jumlah & Prosentase \\
\hline Kurang & 7 & $28 \%$ \\
\hline Cukup & 8 & $32 \%$ \\
\hline Baik & 10 & $40 \%$ \\
\hline Total & 25 & $100 \%$ \\
\hline
\end{tabular}




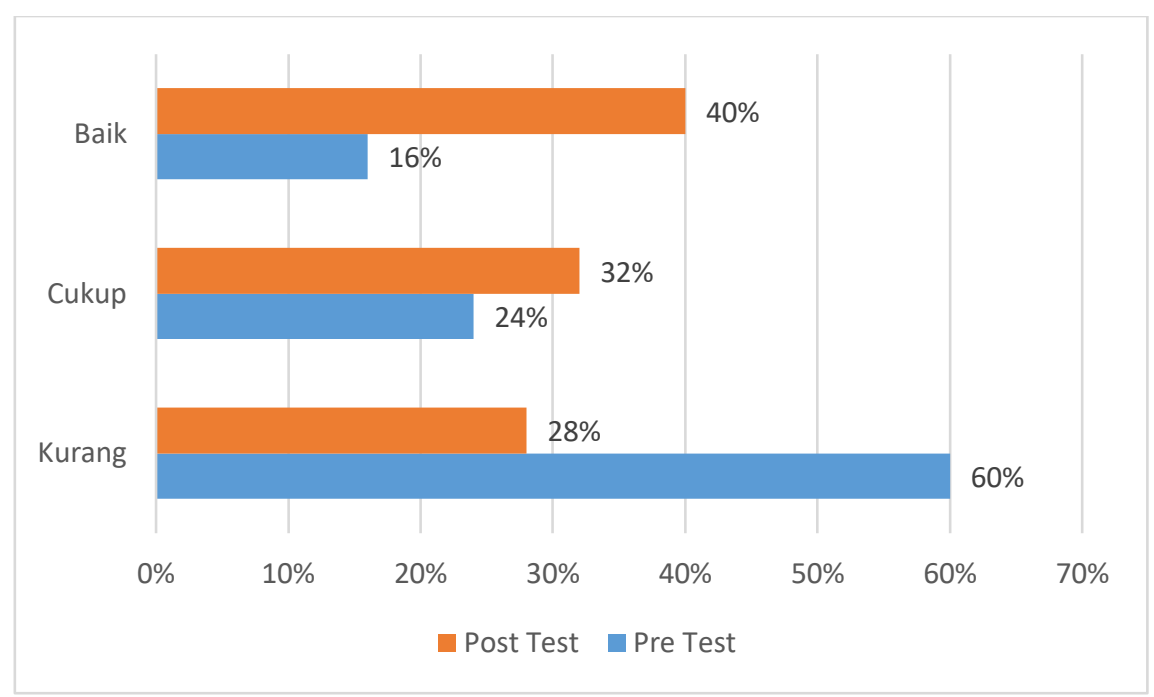

Gambar 2. Perbandingan hasil pre test dan post test

Berdasarkan hasil pre test dan post test tersebut dapat dijabarkan bahwa terjadi peningkatan pengetahuan ibu kader tentang Covid 19 setelah ibu kader mendapatakan pendidikan kesehatan tentang Covid 19.

Berdasarkan gambar 2 tersebut Ibu kader yang mempunyai pengetahuan Baik meningkat dari $16 \%$ menjadi $40 \%$, sedangkan ibu kader yang mempunyai pengetahuan cukup meningkat dari sebelumnya $24 \%$ menjadi $32 \%$. Ibu kader yang mempunyai pengetahuan kurang mengalami penurunan dari $60 \%$ menjadi $28 \%$ hal ini menandakan pelatihan yang diberikan mampu meningkatkan pengetahuan ibu kader tentang pencegahan Covid 19.

Menurut Notoatmodjo (2010) pengetahuan dapat dipengaruhi oleh salah satunya adalah pengalaman. Pengalaman seseorang sangat mempengaruhi pengetahuan, semakin banyak pengalaman seseorang tentang suatu hal, maka akan semakin bertambah pula pengetahuan seseorang akan hal tersebut.

Menurut Nanang H (2014) Pengalaman langsung adalah peserta didik diajak mengerjakan atau mempraktekkan secara langsung dan tidak menggunakan perantara apapun tentang materi yang hendak diajarkan.

Pengukuran pengetahuan dapat dilakukan dengan wawancara atau angket yang menyatakan tantang isi materi yang ingin diukur dari subjek penelitian atau responden.

Kendala pada saat pelaksanaan pengabdian tidak terlalu berarti hal ini dikarenakan semua pihak saling bekerjasama denan baik dan kooperatif. Pada awal pelaksanaan kegiatan masih banyak kader yang belum mengetahui secara memadai tentang Covid 19 dikarenakan masih minimnya informasi yang diterima oleh kader.

\section{SIMPULAN}

Berdasarkan hasil evaluasi kegiatan dapat disimpulkan bahwa kegiatan optimalisasi peran kader kesehatan dalam upaya pencegahan Covid 19 di Desa Pasir Lor berlangsung dengan efektif dan efisiens. Hal ini ditunjukan dengan adanya peningkatan pengetahuan kader setelah mengikuti kegiatan tersebut. 
Rencana tindak lanjut dari kegiatan ini adalah bekerja sama dengan kader untuk memberikan hasil edukasi kepada masyarakat tentang pencegahan Covid 19 sehingga dapat tercipta masyarakat yang sehat dan terhindar dari wabah Covid 19 ini serta mlaksanakan posterisasi tentang upaya dalam mencegah penularan Covid 19. Hal ini dimaksudkan untuk mengoptimalkan kegiatan pencegahan covid 19 dan membudayakan prilaku gerakan masyarakat sehat (Germas) di masyarakat.

\section{DAFTAR PUSTAKA}

Direktorat Jenderal Pencegahan dan Pengendalian Penyakit. Pedoman kesiapsiagaan menghadapi infeksi Novel Coronavirus (2019-nCoV). Kemenkes RI; Jakarta: 2020.

Gugus Tugas Percepatan Penanganan $\begin{array}{lll}\text { Covid } 19 & \text { (2020). Pedoman }\end{array}$ Penanganan Cepat Medis dan Kesehatan Masyarakat Covid 19 Di Indonesia

Kemkes RI.(2020) Apa Yang Harus Dilakukan Masyarakat Untuk Cegah Penularan Covid-19?. [Online] Tersedia pada : www. kemkes.go.id [Diakses 4 Maret 2020].
Kemkes RI. 2020. Jaga Diri dan Keluarga Anda dari Virus Corona - Covid19. [Online] Tersedia pada : www. kemkes.go.id [Diakses 4 Maret 2020].

Kemkes RI. (2017). Peraturan menteri kesehatan Republik Indonesia Nomor 27 Tahun 2017 Tentang Pedoman PPI. Pencegahan dan Pengendalian Infeksi (PPI).

Kemkes RI. (2017). Pedoman Kesiapsiagaan Menghadapi MERSCoV di Indonesia.

Kemkes RI. (2017) Wartakesmas Kementerian Kesehatan Republik Indonesia Edisi 01 | 2017[Online] Tersedia pada : www. kemkes.go.id [Diakses 4 Maret 2020].

Notoatmodjo,S. (2010). Metodologi Penelitian Kesehatan. Jakarta : Rineka Cipta.

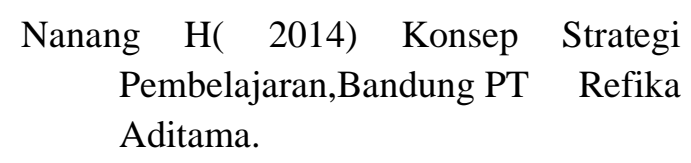

Perhimpunan Dokter Paru Indonesia (2020) Pneumonia Covid-19;Diagnosis \& Penatalaksanaan Di Indonesia 